\title{
ANALISIS PENGARUH PENDAPATAN NASIONAL DAN TINGKAT SUKU BUNGA TERHADAP PENGHIMPUNAN DANA PIHAK KETIGA PADA BANK UMUM DI INDONESIA
}

\author{
Oleh: \\ Khoirunnisa' Arrohmah \\ Alumni Fakultas Ekonomi Universitas Muhammadiyah Malang \\ E-mail/No. Hp: - /085646695664 \\ Aries Soelistyo \\ Fakultas Ekonomi Universitas Muhammadiyah Malang \\ E-mail/No. Hp: - /0818201879
}

\begin{abstract}
The principal problem of this study are associated with the Indonesian economy which needs to be improved, therefore Government could increase through improved and increased banks' performance by increasing the national income, where the banking, especially commercial banks at the core of the financial system of State. The method used in this study is multiple linear regression partial adjustment model (Partial Adjustement Model) that is useful to observe the response of short-term and long-term variable from one unit change in the value of independent variables. From the analysis results obtained equation is LSt $=\beta_{0}+\beta_{1} L Y_{t}+\beta_{2} L r_{t}+\beta_{3} L S t_{-1}+\mu_{t}$. The results showed that the model free from the classical assumption of multicollinearity, heteroscedasticity, autocorrelation. As for all significant independent variables simultaneously on the third party funding variables, this suggests that the third party funding increase is influenced by many factors could be shown the results of the regression is calculated for $679.8788 F<F$ table at 2.48. And partially variable interest rate not significantly affect the third party funding.
\end{abstract}

Keywords: national income, interest rates, DPK.

\section{PENDAHULUAN}

Dalam rangka mewujudkan masyarakat Indonesia yang adil dan makmur berdasarkan Undang-Undang Dasar 1945, maka kesinambungan dan peningkatan pelaksanaan pembangunan nasional yang berazaskan kekeluargaan perlu dipelihara dengan baik. Untuk mencapai tujuan tersebut, maka pelaksanaan pembangunan ekonomi harus lebih memperhatikan keserasian, keselarasan dan keseimbangan unsurunsur pemerataan pembangunan, pertumbuhan ekonomi dan stabilitas nasional. Salah satu sarana yang mempunyai peran strategis untuk menyerasikan dan menyeimbangkan dari masing-masing unsur adalah perbankan. Peran yang strategis tersebut terutama disebabkan oleh fungsi utama bank sebagai suatu wahana yang menghimpun dan menyalurkan dana masyarakat secara efektif dan efisien yang dengan berasaskan demokrasi ekonomi mendukung pelaksanaan pembangunan nasional dalam rangka meningkatkan pemerataan pembangunan dan hasilhasilnya, pertumbuhan ekonomi dan 
stabilitas nasional ke arah peningkatan taraf hidup rakyat.

Perbankan khususnya bank umum merupakan inti dari sistem keuangan setiap negara. Bank merupakan lembaga keuangan yang menjadi tempat bagi perusahaan, badan pemerintah, swasta dan perorangan menyimpan dana. Dalam kegiatan operasionalnya, bank tidak hanya menghimpun dana dalam simpanan (Funding Product) dan menyalurkan dalam bentuk kredit (Lending Product), tetapi juga memberikan jasa-jasa keungan lainnya, yang kesemuanya akan memberikan suatu jasa (fee) bagi bank.

Perbankan sebagai suatu sektor terpenting dalam struktur perekonomian, telah memberikan peranan yang sangat strategis dalam menunjang perkembangan dan pertumbuhan ekonomi. Sebaliknya, perkembangan dan pertumbuhan ekonomi yang dicapai telah mendorong dan memberikan peluang bagi perkembangan dan pertumbuhan industri di Indonesia.

Dana bank yang berasal dari masyarakat dapat diwujudkan dalam bentuk giro (demand deposit), deposito (time deposito), dan tabungan (saving account). Faktor-faktor penting yang mempengaruhi penghimpunan dana atau simpanan deposito salah satunya adalah tingkat pendapatan, dimana semakin tinggi tingkat pendapatan, maka semakin besar pula tingkat tabungan yang diciptakan masayarakat. Hal ini berarti ada pengaruh yang positif antara pendapatan dan jumlah tabungan J.M Keynes mengatakan bahwa ada pendapatan merupakan hal yang penting bagi tabungan dan tingkat bunga, karena suku bunga tergantung pada penawaran dan permintaan uang, dan tidak tergantung pada tabungan serta investasi. J.M Keynes juga berpendapat bahwa pendapatan masyarakat digunakan sebagian untuk konsumsi dan sebagian lainnya digunakan untuk menabung. Pendapatan tentunya sangat berpengaruh terhadap jumlah tabungan yang disimpan masyarakat di lembaga-lembaga perbankan, dalam arti semakin besar pendapatan semakin besar pula tingkat tabungan masyarakat, jika pendapatan meningkat jumlahnya, maka dana masyarakat yang berhasil dihimpun oleh lembaga perbankan ada kecenderungan meningkat.

Faktor lain yang mempengaruhi pertumbuhan penghimpunan dana masyarakat adalah besar kecilnya tingkat suku bunga yang berlaku, dalam arti semakin tinggi tingkat bunga yang ditawarkan, semakin besar pula keinginan masyarakat untuk menyisihkan sebagian pendapatannya yang dikonsumsi untuk disimpan dalam bentuk tabungan. Dengan demikian, semakin tinggi tingkat suku bunga akan mendorong keinginan masyarakat untuk menabung. Sehingga hal tersebut juga berpengaruh terhadap kegiatan operasionalnya bank baik dalam menghimpun dana maupun dalam menyalurkan dana.

Berdasarkan uraian tersebut maka penelitian ini bertujuan untuk mengetahui pengaruh antara variabel pendapatan nasional dan tingkat suku bunga terhadap penghimpunan dana pihak ketiga pada bank umum di Indonesia (2004-2007).

\section{TINJAUAN PUSTAKA}

Penelitian yang sekiranya memiliki topik yang sama dengan penelitian yang sedang adalah hasil penelitian yang dilakukan oleh Dwi Fatmawati (2007) yang berjudul "Analisis faktor-faktor yang mempengaruhi penghimpunan dana masyarakat pada bank umum di wilayah Jawa Timur (1996-2006)". Adapun hasil dari penelitian tersebut menunjukkan bahwa nilai $t_{\text {hitung }}$ variabel tingkat suku bunga $\left(\mathrm{X}_{1}\right)$ sebesar 2.967, sedangkan 
$\mathrm{t}_{\text {tabel }}$ yang diperoleh 2.262 maka $\mathrm{H}_{\mathrm{o}}$ ditolak dan $\mathrm{H}_{\mathrm{a}}$ diterima sehingga ada pengaruh positif antara tingkat suku bunga terhadap penghimpunan dana masyarakat. Dan $t_{\text {hitung pada variabel }}$ pendapatan perkapita (X2) sebesar 12.236, sedangkan $t_{\text {tabel }}$ yang diperoleh 2.262, berarti pendapatan perkapita berpengaruh terhadap penghimpunan dana masyarakat. Selain itu terdapat $\mathrm{F}_{\text {hitung }}$ sebesar 76.44 dan $\mathrm{F}_{\text {tabel }} 2.70$ hal ini berarti ada pengaruh signifikan atau serentak pada variabel bebas dan variabel terikat. Jadi besar kecilnya penghimpunan dana masyarakat pada bank umum di wilayah jawa timur dari tahun ke tahun dipengaruhi oleh tingkat suku bunga dan pendapatan perkapita.

Adapun peneliti terdahulu yang lainnya dilakukan oleh Widowati (2006), dengan judul Penentuan tingkat suku bunga dan tingkat produk domestik regional bruto (PDRB) dalam penghimpunan dana simpanan berjangka pada bank-bank swasta di jawa timur (1998-2005). Hasil penelitian menunjukkan bahwa variabel tingkat suku bunga $\left(\mathrm{X}_{1}\right)$ memiliki tingkat signifikansi sebesar 0,796, dengan demikian dapat disimpulkan bahwa tidak ada pengaruh yang signifikan antara variabel suku bunga dengan jumlah deposito. Dan untuk tingkat PDRB $\left(\mathrm{X}_{3}\right)$ pada tingkat signifikansi sebesar 0,012 dapat disimpulkan bahwa ada pengaruh yang signifikan antara variabel PDRB dengan jumlah deposito (Y). Jadi dengan naik turunnya PDRB berpengaruh terhadap tinggi rendahnya deposito yang dihimpun oleh bank swasta di Jawa Timur.

Tingkat suku bunga dan pendapatan merupakan salah satu faktor yang menjadi penentu nasabah untuk menyimpan dananya pada lembaga perbankan. Dalam penelitian ini, diharapkan dapat membuktikan bahwa pendapatn nasional, dan tingkat suku bunga dapat memberikan pengaruh yang signifikan terhadap penghimpunan dana pihak ketiga pada bank umum di Indonesia.

Menurut Keynes, besarnya tabungan yang dilakukan oleh rumahtangga bukan tergantung kepada tinggi rendahnya tingkat bunga. Hal ini terutama tergantung kepada besar kecilnya tingkat pendapatan rumahtangga itu. Makin besar jumlah pendapatan yang diterima oleh sesuatu rumahtangga, makin besar tingkat bunga sehingga makin banyak pula jumlah tabungan yang dilakukannya. Besarnya pendapatan mempengaruhi besarnya tingkat suku bunga. Apabila tingkat pendapatan nasional rendah, tabungan masyarakat negatif. Sedangkan semakin tinggi pendapatan nasional, semakin banyak tabungan masyarakat. Sehingga hal ini akan berpengaruh positif pendapatan nasional terhadap penghimpunan dana pihak ketiga.

Hubungan Tingkat Suku Bunga Terhadap Penghimpunan Dana Pihak Ketiga, Pandangan kaum klasik ini dapat dijumpai dalam teori leonable funds. Dalam teori ini disebutkan bahwa tingkat bunga adalah harga yang dibayarkan atas penggunaan dana untuk setiap unit waktu dan ditentukan melalui interkasi permintaan dan penwaran dana

Menurut teori Klasik, tingkat bunga pada perekonomian yang akan mempengaruhi tabungan (saving) yang terjadi. Berarti keinginan masyarakat untuk menabung sangat tergantung pada tingkat bunga, semakin tinggi tingkat bunga, semakin besar keinginan masyarakat untuk menabung atau masyarakat akan terdorong untuk mengorbankan pengeluaran guna menambah besarnya tabungan. Jadi tingkat suku bunga menurut klasik adalah balas jasa yang diterima seseorang karena menabung atau hadiah 
yang diterima seseorang karena menunda konsumsinya.

\section{METODE PENELITIAN}

Pada penelitian ini sampel yang digunakan yaitu bank umum. Bank umum yang dimaksud meliputi: Bank Persero, Bank Pemerintah, Bank Swasta Nasional, Bank Asing dan Bank Campuran pada tahun 2004-2007 dalam bentuk bulanan.

Dalam penelitian ini data yang digunakan berupa data kuantitatif yang berasal dari data sekunder. Yaitu berupa data berkala (data time series) selama 5 tahun dalam bentuk bulanan dari tahun 2004-2007 untuk data penghimpunan dana pada bank umum, jumlah uang beredar dan tingkat suku bunga. Data tersebut diperoleh dari beberapa instansi yang terkait yaitu Bank Indonesia yang telah dipublikasikan lewat media elektronik yaitu internet dengan alamat websitenya yaitu www.bo.go.id dan diambil dari Statistik Ekonomi Indonesia yang dikeluarkan oleh Bank Indonesia.

Model Analisis, Hubungan Dana Pihak ketiga (asumsi terhadap saving) dipengaruhi dengan pendapatan nasional dan tingkat suku bunga. Adapun model sederhana yang menjelaskan bahwa Dana pihak ketiga diharapkan dipengaruhi oleh pendapatan nasional (Y) dan suku bunga (r).

$\mathrm{St}^{*}=\alpha_{0}+\alpha_{1} \mathrm{Y}_{\mathrm{t}}+\alpha_{2} \mathrm{r}_{\mathrm{t}}+\mathrm{e}$

Dimana:

$\mathrm{St}^{*}=$ Penghimpunan dana pihak ketiga yang diharapkan

$\mathrm{Y}_{\mathrm{t}} \quad=$ Pendapatan Nasional

$\mathrm{r}_{\mathrm{t}} \quad=$ Tingkat suku bunga

$\alpha_{0}, \alpha_{1}, \alpha_{2}=$ Konstanta

$\mathrm{e}_{\mathrm{t}} \quad=$ error term

Dana pihak ketiga akan disesuaikan kepada dana pihak ketiga riil (Y) melalui proses penyesuaian dengan tingkat persamaan (coeficient of adjustment) $0<\delta<1$.
Karena nilai dari penghimpunan dana pihak ketiga optimal St* tidak didapatkan datanya di lapangan maka dideteksi melalui penyesuaian persediaan atau Partial Adjustment Model (PAM). Jika St* adalah penghimpunan dana pihak ketiga pada periode $\mathrm{t}$ dan $\mathrm{St}$ adalah nilai aktual penghimpunan dana maka model penyesuaian persediaan atau PAM dapat dijelaskan sebagai beikut:

$\mathrm{St}-\mathrm{St}_{-1}=\delta\left(\mathrm{St}^{*}-\mathrm{St}_{-1}\right)$

Persamaan (2) bisa ditulis kembali

menjadi:

$\mathrm{St}=\delta \mathrm{St}^{*}+(1-\delta) \mathrm{St}^{-} 1$

Dimana:

St* = Penghimpunan dana pihak ketiga yang diharapkan

$\delta=$ Koefisien penyesuaian besarnya 0 $<\delta<1$

Agar persamaan (1) dapat dicari solusinya maka persamaan disubstitusikan ke dalam persamaan (2) sehingga menghasilkan persamaan sebagai berikut:

$\mathrm{St}=\delta\left(\alpha_{0}+\alpha_{1} \mathrm{Y}_{\mathrm{t}}+\alpha_{2} \mathrm{r}_{\mathrm{t}}+\mathrm{e}_{\mathrm{t}}\right)+(1-\delta) \mathrm{St}_{-1}$

$\mathrm{St}=\delta \alpha_{0}+\delta \alpha_{1} \mathrm{Y}_{\mathrm{t}}+\delta \alpha_{2} \mathrm{r}_{\mathrm{t}}+(1-\delta) \mathrm{St}_{-1}+v_{\mathrm{t}}(3)$

Dimana: $\mathrm{v}_{\mathrm{t}}=\delta \mathrm{e}_{\mathrm{t}}$

Jika:

$\delta \alpha_{0} \quad=\beta_{0}$

$\delta \alpha_{1} \quad=\beta_{1}$

$\delta \alpha_{2}=\beta_{2}$

$(1-\delta)=\beta_{3}$

$\mathrm{v}_{\mathrm{t}} \quad=\mathrm{e}_{\mathrm{t}}$

Maka model empiris ekonometrik DPK diharapkan ditullis sebagai berikut:

$\mathrm{St}=\beta_{0}+\beta_{1} \mathrm{Y}_{\mathrm{t}}+\beta_{2} \mathrm{r}_{\mathrm{t}}+\beta_{3} \mathrm{St}-_{1}+\mathrm{e}_{\mathrm{t}}$

Dimana:

$\mathrm{St}$

Yt = Pendapatan Nasional

$\mathrm{r}_{\mathrm{t}} \quad=$ Tingkat suku bunga

$\beta_{0}, \beta_{1}, \beta_{2}, \beta_{3} \quad=$ Konstanta

$\mathrm{e}_{\mathrm{t}} \quad=$ error term

Catatan: 1. Koefisien parameter dalam persamaan (4) menunjukkan hubungan jangka pendek antara variabel dependent 
dengan variabel independent; 2. Koefisien parameter dalam persamaan (1) menunjukkan hubungan jangka panjang.
a) $\beta_{3}=1-\delta$
c) $\beta_{1}=\delta \alpha_{1}$
$\delta=1-\beta_{3}$ $\alpha_{1}=\frac{\beta 1}{\delta}=\frac{\beta}{1-\beta 3}$
b) $\beta_{0}=\delta \alpha_{0}$

$$
\alpha_{0}=\frac{\beta o}{\delta}=\frac{\beta}{1-\beta 3}
$$
d) $\beta_{2}=\delta \alpha_{2}$

$$
\alpha_{2}=\frac{\beta 2}{\delta}=\frac{\beta}{1-\beta 3}
$$
Agar data berbentuk linier maka dalam penelitian ini semua variabel dilogkan terlebih dahulu sehingga model persamaan jangka pendek menjadi:

$\mathrm{LSt}=\beta_{0}+\beta_{1} \mathrm{LY}_{\mathrm{t}}+\beta_{2} \mathrm{Lr}_{\mathrm{t}}+\beta_{3} \mathrm{LSt}_{-1}+\mu_{\mathrm{t}}$ Dimana, LSt $=$ Log Penghimpunan dana pihak ketiga jangka pendek; $\mathrm{LY}_{\mathrm{t}}=\mathrm{Log}$ Pendapatan Nasional; $\operatorname{Lr}_{\mathrm{t}}=\log$ tingkat suku bunga.

Seperti yang terlihat di atas, dalam persamaan regresi linier dimasukkan nilai lag (keterlambatan) variabel terikat sebagai salah satu variabel bebas, sehingga model regresi ini disebut model autoregresif. Dimana dalam model ini melibatkan regresi variabel terikat atau lag variabel itu sendiri untuk periode waktu tertentu.

Menurut Damodar Gujarati (1997:255), ada beberapa alasan mengapa model ini digunakan antara lain: yaitu alasan psikologis, teknis dan kelembagaan. Sebagai akibatnya, suatu variabel terikat ekonomis mungkin memerlukan waktu untuk menanggapi suatu variabel penentu yang bersifat ekonomis. Dengan kata lain model, autoregresif ini memperhitungkan secara eksplisit peranan dari waktu yang dapat membantu kita untuk membedakan antara respon jangka pendek dan jangka panjang dari variabel terikat terhadap satu unit perubahan pada nilai variabel bebas.

Oleh karena itu, dalam penelitian yang ingin diketahui pengaruh variabel makro ekonomi terhadap penghimpunan dana digunakan model autoregresif dengan memasukan variabel penghimpunan dana periode sebelumnya sebagai salah satu variabel bebas dan model di atas dikenal sebagai model penyesuaian (PAM).

Dikarenakan ada kelambanan, maka koefisien jangka panjang dapat diketahui dengan rumus sebagai berikut:

$=\frac{\text { Coeficient Variabel Bebas }}{(1-\text { Coeficient Variabel Lag })}$

Untuk mengetahui variabel bebas manakah yang memberi pengaruh paling besar terhadap variabel terikat dilihat dari besarnya probabilitas. Semakin kecil nilai probabilitas, maka semakin besar pula pengaruh yang ditimbulkan variabel bebas tersebut terhadap variabel terikat.

\section{PEMBAHASAN}

Jumlah penghimpunan dana pihak ketiga merupakan variabel dependent yang mencerminkan jumlah dana yang dihimpun dari masyarakat dalam bentuk giro, tabungan, deposito berjangka, dimana besar kecilnya simpanan dana masyarakat dipengaruhi pendapatan nasional dan tingkat suku bunga.

Berdasarkan tabel 1, dapat diketahui bahwa perkembangan penghimpunan dana pihak ketiga yang meliputi: giro, tabungan, simpanan berjangka pada bank umum di Indonesia terjadi peningkatan dari tahun 20042007. Pada giro tahun 2004 sebesar 171,660 miliar rupiah sampai tahun 2007 meningkat menjadi 311,037 miliar rupiah. Begitu juga terjadi pada simpanan berjangka dari tahun 2004 hingga 2007 terjadi peningkatan yang baik dari 352,723 miliar rupiah menjadi 543,284 miliar rupiah. Dari rincian diatas dapat dilihat bahwa terjadi fluktuasi pada perkembangan penghimpunan dana dari tahun ke tahun, perkembangan tahun 2006 mengalami kenaikan sebesar $17.59 \%$ dibandingkan tahun 2004 yang hanya sebesar $8.6 \%$. 
Tabel 1. Perkembangan Penghimpunan Dana pada Bank Umum di Indonesia Tahun 2004-2007 (Milliar Rp).

\begin{tabular}{lrrrr}
\hline \multirow{2}{*}{ Penghimpunan Dana } & 2004 & 2005 & 2006 & 2007 \\
\hline Giro & 171,660 & 194,533 & 251,219 & 311,037 \\
Tabungan & 296,202 & 281,601 & 334,363 & 435,309 \\
Simpanan Berjangka & 352,723 & 456,739 & 551,357 & 543,284 \\
Total & 820,585 & 932,873 & $1,096,939$ & $1,289,630$ \\
Perkembangan (\%) & 8.6 & 13.68 & 17.59 & 17.56 \\
\hline Sumber : Statistik Ekonomi Keuangan Indonesia, (Data Diolah)
\end{tabular}

Peningkatan penghimpunan dana tersebut merupakan dampak dari beberapa kebijakan yang telah dikeluarkan oleh pemerintah salah satunya dengan meningkatkan tingkat suku bunga dalam rangka menstabilkan dana menekan uang beredar yang dapat meningkatkan laju inflasi dan nilai rupiah yang dilakukan sejak terjadinya krisis

Sedangkan penurunan penghimpunan dana terjadi karena kecenderungan turunnya suku bunga SBI yang berakibat langsung pada menurunnya suku bunga deposito sehingga masyarakat cenderung mengalihkan dananya simpanan yang berjangka lebih pendek atau alternatif investasi lainnya.

Tingginya tingkat suku bunga bagi masyarakat cukup menarik perhatian, sehingga masyarakat menggunakan kesempatan ini untuk menyimpan kelebihan dana mereka pada bank-bank umum yang dianggap mempunyai tingkat kreditabilitas yang tinggi. Hal ini menunjukkan bahwa disamping ingin mendapat keuntungan yang lebih besar, masyarakat juga memperhatikan kreditabilitas bank.

Dana masyarakat yang disimpan dalam bank merupakan modal terbesar yang diandalkan. Ada tiga jenis simpanan yang paling diminati oleh masyarakat dan merupakan sumber dana yang diperoleh oleh bank sebagai prioritas utama modal bank, selain modal sendiri dan modal dari pihak lain. Tiga jenis simpanan yang dianggap menguntungkan bagi masyarakat maupun bank itu sendiri yaitu : Giro, Simpanan berjangka, Tabungan.

Adapun perkembangan pendapatan nasional di Indonesia dapat dilihat pada tabel berikut:

Tabel 2. Perkembangan Pendapatan Nasional di Indonesia Tahun 2004-2007 (Miliar Rp)

\begin{tabular}{cccr}
\hline Tahun & PDB & $\begin{array}{c}\text { Perubahan } \\
\text { (Miliar) }\end{array}$ & $\begin{array}{c}\text { Perubahan } \\
(\%)\end{array}$ \\
\hline 2004 & 193144.22 & - & - \\
2005 & 241095.98 & 47951.76 & 24.83 \\
2006 & 279287.94 & 38191.96 & 15.84 \\
2007 & 335636.21 & 56348.27 & 20.17 \\
\hline Sumber : Statistik Ekonomi Keungan Indonesia, \\
(Data Diolah)
\end{tabular}

Berdasarkan data yang diperoleh, dapat diketahui bahwa pendapatan nasional terus terjadi peningkatan. Kenaikan tersebut sangat mempengaruhi terhadap pertumbuhan penghimpunan dana. Dalam suatu perekonomian tingkat pertumbuhan tinggi, orang akan cenderung untuk berinvestasi. Hal ini disebabkan bahwa Negara-negara dengan pendapatan tinggi juga mengalami pertumbuhan yang pesat dan sebaliknya. Pada tahun 2007 mengalami kenaikan sebesar 56348.27 miliar rupiah meskipun dengan prosentase kecil yaitu 
$20.17 \%$ dibandingkan prosentase tahun 2005.

Tingkat suku bunga merupakan salah satu faktor yang menjadi penentu masyarakat untuk menghimpun dananya pada lembaga perbankan. Perkembangan tingkat suku bunga dapat digambarkan sebagai berikut:

Tabel 3. Perkembangan Rata-rata Suku Bunga pada Bank Umum Tahun 2004-2007 (Miliar Rp)

\begin{tabular}{ccrr}
\hline Tahun & $\begin{array}{c}\text { Rata-rata } \\
\text { Suku } \\
\text { Bunga }\end{array}$ & $\begin{array}{c}\text { Perkemban } \\
\text { gan (satuan } \\
\%)\end{array}$ & $\begin{array}{c}\text { Perkemban } \\
\text { gan (\%) }\end{array}$ \\
\hline 2004 & 7.0900 & - & - \\
2005 & 10.428 & 3.338 & 47.08 \\
2006 & 10.568 & 0.14 & 1.34 \\
2007 & 8.266 & -2.302 & -21.78 \\
\hline Sumber : Statistik Ekonomi Keuangan Indonesia,
\end{tabular}
(Data Diolah)

Dari tabel diatas dapat diketahui bahwa suku bunga deposito dalam bentuk 1bulan mengalami fluktuasi pada setiap tahun. Pada tahun 2005 mengalami peningkatan yang tajam sebesar $47.08 \%$, dibandingkan tahun 2007 dengan kenaikan hanya sebesar $21.78 \%$. Sedangkan pada tahun 2006 mengalami peningkatan sebesar $10.568 \%$ meskipun dengan prosentase kecil yaitu $1.34 \%$.

Kenaikan yang sangat tajam yang dialami tahun 2005 disebabkan karena di Indonesia mengalami krisis dan inflasi, sehingga salah satu upaya pemerintah untuk mengatasinya adalah dengan menekan uang beredar baik dalam arti sempit maupun arti luas atau likuiditas perekonomian, dari efek kebijakan tersebut bank-bank umum berlombalomba menaikkan suku bunga. Bunga yang diberikan oleh bank pada masyarakat merupakan daya tarik yang utama bagi masyarakat untuk melakukan penyimpanan uangnya di bank, sedangkan bagi bank, semakin besar dana masyarakat yang bisa dihimpun, akan meningkatkan kemampuan bank untuk membiayai operasional aktivanya yang sebagian besar berupa pemberian kredit pada masyarakat.

Dari hasil pengujian model yang digunakan dalam penelitian ini dapat diketahui bahwa variabel bebas pendapatan nasional, tingkat suku bunga, penghimpunan dana pihak ketiga periode sebelumnya berpengaruh terhadap vaiabel terikat penghimpunan dana pihak ketiga. Hasil pengujian model regresi dapat ditunjukkan sebagai berikut:

Tabel 4. Hasil Estimasi Regresi

\begin{tabular}{lcccc}
\hline $\begin{array}{c}\text { Variabel } \\
\text { Bebas }\end{array}$ & $\begin{array}{c}\text { Koef. } \\
\text { Regresi }\end{array}$ & $\begin{array}{c}\text { Simp. } \\
\text { Baku }\end{array}$ & $\begin{array}{c}\text { T- } \\
\text { hitung }\end{array}$ & Prob \\
\hline $\mathrm{C}$ & 3.2603 & 1.383007 & 2.3574 & 0.0230 \\
$\mathrm{LY}$ & 0.3964 & 0.119460 & 3.3186 & 0.0018 \\
$\mathrm{Lr}$ & 0.0099 & 0.048991 & 0.2030 & 0.8400 \\
$\mathrm{LSt}-1$ & 0.5248 & 0.148081 & 3.5440 & 0.0010 \\
\hline Sumber : Data Diolah \\
$\mathrm{R}^{2}=0.979111 ;$ Adjusted R-Squared $=0.977653 ;$ \\
$\mathrm{F}$ hitung = 671.8289; & Durbin Watson Stat $=$ \\
2.1924682 & & \multicolumn{4}{l}{} \\
\end{tabular}

Berdasarkan hasil perhitungan nilai koefisien determinasi $\left(\mathrm{R}^{2}\right)$ melalui analisa regresi ditunjukkan bahwa variabel pendapatan nasional, tingkat suku bunga, penghimpunan dana pihak ketiga periode sebelumnya mampu menjelaskan $97.91 \%$ variasi besarnya penghimpunan dana pihak ketiga. Sedangkan sisanya $2,09 \%$ menunjukkan bahwa variasi besarnya penghimpunan dana pihak ketiga dijelaskan oleh variabel lain yang mempunyai pengaruh namun tidak diamati dalam penelitian ini. Variabel lain yang dimaksud dapat berupa variabel ekonomi dan nonekonomi yang berpengaruh langsung terhadap variabel-vaiabel yang mempengaruhi besarnya penghimpunan dana pihak ketiga. Oleh karena persentase variasi besarnya penghimpunan dana pihak ketiga yang tidak dapat dijelaskan adalah kecil, maka dapat dikatakan bahwa model yang digunakan adalah baik. 
Berdasarkan hasil analisa regresi atas model yang digunakan dalam penelitian ini, diperoleh persamaan regresi linier berganda untuk besarnya penghimpunan dana pihak ketiga adalah: $\mathrm{LS}=3.260344+0.396443 \mathrm{LY}+$

$0.009948 \mathrm{Lr}+0.524806 \mathrm{LS}_{\mathrm{t}-1}+\mathrm{e}_{\mathrm{t}}$

Dari model di atas diperoleh nilai koefisien regresi $(\beta)$ dimana koefisien $\beta$ yang menunjukkan seberapa besar perubahan besarnya penghimpunan dana pihak ketiga jika terjadi perubahan secara individual pada variabel pendapatan nasional, tingkat suku bunga dan penghimpunan dana pihak ketiga periode sebelumnya, jika variabel lain tidak berubah atau konstan.

Adapun pengaruh dari masingmasing variabel bebas terhadap variabel besarnya penghimpunan dana pihak ketiga dapat dijelaskan sebagai berikut: Pendapatan Nasional, Variabel ini berpengaruh secara signifikan terhadap penghimpunan dana pihak ketiga. Dapat dilihat dari nilai $t_{\text {hitung }}$ yang lebih besar dari $\mathrm{t}_{\text {tabel }}$ atau dapat dilihat dari nilai probabilitasnya, yaitu apabila probabilitas atau tingkat signifikansinya dibawah 0.05 maka dapat dikatakan variabel tersebut lolos uji $\mathrm{t}$ dan nilai probabilitasnya sebesar 0,0018 .

Koefisien variabel sebesar 0.396443 menunjukkan bahwa apabila pendaptan nasonal naik sebesar $1 \%$ akan mengakibatkan kenaikan pada penghimpunan dana pihak ketiga sebesar $39.64 \%$ cateris paribus.

Tingkat suku bunga, Dari hasil uji t dapat dilihat bahwa variabel tingkat suku bunga tidak berpengaruh signifikan terhadap penghimpunan dana pihak ketiga. Hasil uji-t menunjukkan bahwa $\mathrm{t}_{\text {hitung }}$ yang diperoleh sebesar 0.203066 sedangkan $t_{\text {tabel }}$ sebesar 2,021, dapat juga dilihat dari nilai probabilitasnya yang lebih besar dari 0,05 maka variabel tersebut tidak lolos uji $\mathrm{t}$ dan nilai probabilitasnya sebesar 0.8400 .
Koefisien variabel sebesar 0.009948, menunjukkan bahwa apabila suku bunga mengalami kenaikan sebesar $1 \%$ maka penghimpunan dana pihak ketiga turun sebesar $0.9948 \%$ dan sebaliknya, dengan asumsi variabel lain konstan.

Penghimpunan Dana Pihak Ketiga periode sebelumnya, Berdasarkan hasil uji-t, besarnya penghimpunan dana pihak ketiga periode sebelumnya berpengaruh signifikan terhadap besarnya penghimpunan dana pihak ketiga. Artinya perubahan yang terjadi pada besarnya penghimpunan dana pihak ketiga periode sebelumnya akan mempengaruhi perubahan penghimpunan dana pihak ketiga. Koefisien regresi untuk variabel penghimpunan dana pihak ketiga periode sebelumnya memiliki tanda positif yang berarti apabila besarnya penghimpunan dana pihak ketiga periode sebelumnya naik maka akan menaikkan besarnya penghimpunan dana pihak ketiga.

Sedangkan nilai koefisien regresi yang diperoleh sebesar 0.524806 artinya jika besarnya penghimpunan dana pihak ketiga periode sebelumnya naik $1 \%$ maka besarnya penghimpunan dana pihak ketiga akan meningkat sebesar $52.48 \%$. Sedangkan untuk mengetahui pengaruhnya dalam jangka panjang maka pada fungsi besarnya penghimpunan dana pihak ketiga jangka panjang, variabel kelambanan $\left(\mathrm{S}_{\mathrm{t}-1}\right)$ dikeluarkan dan seluruh koefisien regresi fungsi jangka pendek dibagi $\delta=1$ $52.48=-51.48$. Sehingga diperoleh fungsi besarnya penghimpunan dana pihak ketiga jangka panjang adalah sebagai berikut:

$$
\mathrm{LS}=(-6.3332)+7.5520 \mathrm{LY}+1.8950 \mathrm{Lr}
$$

Dari fungsi tersebut di atas, dapat diketahui bahwa Elastisitas pendapatan nasional jangka panjang terhadap besarnya penghimpunan dana pihak ketiga 7.5520 jauh lebih besar daripada 
elastisitas jangka pendeknya sebesar 0.3964 .

Sedangkan elastisitas tingkat suku bunga jangka panjang terhadap penghimpunan dana pihak ketiga 1.8950 adalah lebih besar daripada elastisitas jangka pendeknya sebesar 0.0099 .

Untuk mengetahui variabel yang mempunyai pengaruh paling dominan terhadap besarnya penghimpunan dana pihak ketiga selama periode penelitian tahun 2004 sampai dengan 2007 dapat dilihat nilai probabilitas. Variabel bebas memiliki nilai probabilitas yang terendah menunjukkan bahwa variabel tersebut merupakan variabel yang memiliki pengaruh dominan terhadap variabel terikat.

Berdasarkan hasil perhitungan diperoleh nilai probabilitas untuk variabel pendapatan nasional, tingkat suku bunga serta penghimpunan dana pihak ketiga periode sebelumnya masing-masing sebesar 0,0018; 0.8400; 0,0010 . Dengan membandingkan nilai probabilitas dari masing-masing variabel dapat diambil kesimpulan bahwa variabel yang mempunyai pengaruh paling dominan terhadap besarnya penghimpunan dana pihak ketiga adalah penghimpunan dana pihak ketiga periode sebelumnya. Hal ini disebabkan masyarakat cenderung menganalisa penghimpunan dana pihak ketiga yang dimiliki periode sebelumnya serta sesuai dengan model yang digunakan dalam penelitian ini yaitu model penyesuaian parsial (Partial Adjustment Model).

Variabel lain di luar variabel besarnya penghimpunan dana pihak ketiga periode sebelumnya yang memiliki pengaruh dominan terhadap besarnya penghimpunan dana pihak ketiga jika dilihat nilai koefisien adalah pendapatan nasional.

Berdasarkan hasil penelitian tersebut bahwa pendapatan nasional berpengaruh secara langsung terhadap penghimpunan dana pihak ketiga. Hal ini dapat dijelaskan bahwa pada saat masyarakat atau nasabah berpendapatan rendah maka masyarakat tersebut belum mampu menyisihkan sebagian pendapatannya untuk ditabung, Karena seluruh pendapatannya meningkat atau pendapatan yang diperoleh lebih besar dari kebutuhan konsumsinya artinya ada kelebihan pendapatan yang dapat disisihkan untuk ditabung. Apabila dalam periode berikutnya yang diterima turun maka masyarakat akan menurunkan porsi tabungannnya untuk dapat tetap memenuhi kebutuhan konsumsinya.

Karena itu perlu diupayakan untuk mendorong peningkatan pendapatan nasional. Diantaranya melalui kebijakankebijakan yang dapat mendongkrak peningkatan tersebut diantaranya kebijakan ekspor sehingga penerimaan ekspor menjadi meningkat. Karena sektor ekspor berpengaruh positif terhadap pendapatan nasional. Serta perlunya menjaga stabilitas politik dalam negeri sehingga tidak berdampak pada dunia bisnis.

Tingkat suku bunga tidak berpengaruh secara signifikan terhadap penghimpunan dana pihak ketiga. Hal ini menunjukkan bahwa faktor tingkat suku bunga tidak lagi merupakan hal yang menarik atau mendorong nasabah untuk menyimpan dananya pada bank. Sejak terjadi krisis moneter tahun 1997/1998 dimana banyak bank yang bermasalah dalam penghimpunan dana pihak ketiga dalam artian tidak mampu menyelesaikan kewajibannya kepada para deposan maka masyarakat sebagai deposan lebih mempertimbangkan faktor keamanan dan pelayanan. Pada saat pendapatan masyarakat tinggi, maka investasi juga akan naik dan nilai tingkat suku bunga akan turun dan sebaliknya apabila tingkat pendapatan masyarakat turun maka investasi juga akan turun dan 
nilai tingkat suku bunga akan naik. Hal ini disebabkan jika pendapatan masyarakat tinggi meskipun nilai tingkat suku bunga rendah maka masyarakat akan cenderung melakukan investasi hal ini dikarenakan ada kelebihan dana di masyarakat.

Dengan pendapatan yang lebih tersebut masyarakat dapat menyisihkannya sebagian penadapatannya untuk ditabung tanpa menghiraukan besar kecilnya tingkat suku bunga bank. Karena pendapatan sangat mempengaruhi tabungan, sedangkan pendapatan dan uang yang beredar mempunyai hubungan negatif terhadap tingkat bunga. meningkatnya uang yang diedarkan ke masyarakat akan mengakibatkan terjadinya kelebihan pasokan sehingga pada tingkat pendapatan tertentu tingkat suku bunga akan menurunkan keseimbangan pasar.

Berikutnya model diuji dengan asumsi klasik. Uji Normalitas, nilai JB statistik adalah 78.72365 dan nilai $\mathrm{X}_{\text {tabel }}^{2}$ diperoleh dengan $\alpha=5 \%$ dan $\mathrm{df}=43$ sebesar 79.4900. Sehingga JB statistik lebih kecil dari $\mathrm{X}_{\text {tabel }}$ (JB statistik < $\mathrm{X}_{\text {tabel }}^{2}$ ) yang dapat disimpulkan bahwa model yang digunakan yang digunakan mempunyai residual atau faktor pengganngu yang berdistribusi normal tidak dapat ditolak atau data yang digunakan berdistribusi dengan normal.

Uji Linieritas, diketahui bahwa nilai $F$ hitung sebesar 2.234914 sedangkan nilai $F$ tabel dengan $\alpha=5 \%, \mathrm{df}_{1}=3, \mathrm{df}_{2}=43$ sebesar 2.84 .

Sehingga $\mathrm{F}_{\text {hitung }}<\mathrm{F}$ tabel maka hipotesis nol $\left(\mathrm{H}_{0}\right)$ yang menyatakan bahwa spesifikasi model yang digunakan dalam bentuk fungsi linier adalah benar diterima.

Uji Autokorelasi, Kesimpulan: du $<\mathrm{d}<4-$ du atau 1,617 $<2.192<2,341$, berarti Ho diterima dan $\mathrm{Ha}$ ditolak sehingga dapat disimpulkan tidak terjadi autokorelasi, tidak ada korelasi antara variabel pengganggu ( $\mu \mathrm{i})$ yang satu dengan variabel pengganggu ( $\mu \mathrm{i})$ observasi lainnya atau tidak terjadi autokorelasi.

Uji Multikolinieritas, dari hasil regresi diatas, menunjukkan bahwa besarnya $R^{2}=0.232863$, sementara $r^{2}$ masing-masing sebesar 0.216186 . Dengan demikian, berarti apabila nilai $\mathrm{R}^{2}>\mathrm{r}^{2}$ maka tidak ditemukan terjadi multikolinieritas, dan sebaliknya apabila nilai $\mathrm{R}^{2}<\mathrm{r}^{2}$ maka terjadi multikolinieritas. Penunjukkan bahwa nilai $\mathrm{R}^{2}=0.232863$ dan nilai $\mathrm{r}^{2}=$ 0.216186 , berarti nilai $\mathrm{R}^{2}=0.232863>$ $r^{2}=0.216186$, berarti tidak terjadi multikolinieritas secara nyata antara variabel bebas atau Ho diterima dan $\mathrm{Ha}$ ditolak.

Uji Heteroskedastisitas, dari hasil uji white menunjukkan besarnya nilai $\mathrm{X}_{\text {hitung (nilai Obs*R-squared) sebesar }}^{2}$ 20.12370 dan nilai $\mathrm{X}_{\text {tabel }}^{2}$ dengan $\alpha=5 \%$ dan df $=43$ sebesar 66.7659 sehingga nilai $\mathrm{X}_{\text {hitung }}^{2}\left(\mathrm{Obs}^{*} \mathrm{R}\right.$-Squared) < dari $\mathrm{X}_{\text {tabel}}^{2}$, maka hipotesis yang menyatakan ada masalah heteroskedastisitas dalam model empiris yang digunakan ditolak. Dengan kata lain tidak lolos dari masalah heterokedastisitas.

\section{PENUTUP}

Dari analisa data yang telah dilakukan menunjukkan bahwa variabel pendapatan nasional, tingkat suku bunga, dan penghimpunan dana pihak ketiga periode sebelumnya ternyata secara simultan mempunyai pengaruh yang signifikan terhadap besarnya penghimpunan dana pihak ketiga. Hal tersebut dapat dilihat dari $\mathrm{F}$ hitung sebesar 671.8289 lebih besar dari F tabel yaitu sebesar 2.48.

Variabel pendapatan nasional mempunyai pengaruh positif terhadap besarnya penghimpunan dana pihak ketiga dalam jangka pendek. Hal ini dapat dilihat dari t-hitung dari variabel 
pendapatan nasional 3.3186 yang lebih besar dari t-tabel yaitu 2,021 dan nilai koefisien regresi sebesar 0.396443 . Sedangkan untuk variabel tingkat suku bunga tidak berpengaruh secara positif terhadap penghimpunan dana pihak ketiga $t_{\text {hitung }}$ sebesar 0.2030 lebih kecil dari $\mathrm{t}$ tabel yaitu 2,021 serta nilai koefisien regresi sebesar 0.009948. Yang berarti bahwa dalam jangka pendek dan panjang kenaikan pendapatan nasional mempunyai pengaruh positif akan menyebabkan kenaikan besarnya tabungan masyarakat. Sedangkan untuk tingkat suku bunga dalam jangka pendek dan jangka panjang tidak mempunyai pengaruh secara langsung pada himpunan msyarakat.

Variabel penghimpunan dana pihak ketiga sebelumnya mempunyai pengaruh positif terhadap besarnya penghimpunan dana pihak ketiga. Hal ini dapat dilihat dari t- hitung dari variabel penghimpunan dana pihak ketiga periode sebelumnya t- hitung sebesar 2.946 lebih besar dari t- tabel yaitu 2.021 serta nilai koefisien regresi sebesar 0.476632 . Yang berarti bawa kenaikan pendapatan nasional dan penghimpunan dana pihak ketiga periode sebelumnya akan menyebabkan kenaikan penghimpunan dana pihak ketiga.

Oleh karena dalam penelitian menggunakan model penyesuaian parsial sesuai hasil analisa data diketahui bahwa variabel besarnya penghimpunan dana pihak ketiga sebelumnya merupakan variabel yang paling dominan dalam mempengaruhi penghimpunan dana pihak ketiga. Namun di luar variabel penghimpunan dana pihak ketiga sebelumnya tersebut diketahui bahwa variabel pendapatan nasional adalah variabel yang paling dominan pengaruhnya terhadap besarnya penghimpunan dana pihak ketiga. Hal ini disebabkan sebagian besar menyisihkan pendapatannya untuk ditabung setelah dikurangi dengan pengeluaran untuk konsumsi.

Peneliti memberikan saran-saran bahwa walaupun variabel tingkat suku bunga tidak dikatakan sebagai variabel yang paling signifikan namun variabel tersebut berpengaruh terhadap penghimpunan dana pihak ketiga pada Bank Umum di Indonesia. Oleh karena itu kebijaksanaan suku bunga harus fleksibel yaitu harus bisa cepat disesuaikan dengan perubahan harga dengan menghitung dan menetapkan suku bunga. Dengan demikian tingkat suku bunga dapat bersaing dengan suku bunga bank lain dan tingkat suku bunga riil tidak terlalu rendah pada waktu harga turun dan tidak terlalu tinggi pada waktu harga naik.

Karena faktor tingkat suku bunga tidak signifikan ,maka diharapkan bank dapat menjaga likuiditas dalam kinerja keungannya untuk menjamin keamanan demi tingkat kepercayaan dan pelayanan kepada nasabah dalam pengembalian dana.

Tingkat bunga tidak signifikan, maka dalam penelitian selanjutnya lebih baik menggunakan model penyesusain adaptif (adaptif ekspectation model), dimana tingkat suku bunga periode sebelumnya dapat mempengaruhi dana pihak ketiga yang diharapkan.

Dalam pengambilan kebijakan yang berhubungan dengan tabungan di Indonesia, seharusnya pemerintah tidak hanya menekankan pada mekanisme yang selama ini dilakukan yaitu meningkatkan dana pension, asuransi dan program jaminan sosial jangka panjang melainkan bagaimana meningkatkan pendapatan nasional. Diantaranya dengan cara memperluas lapangan pekerjaan sehingga pendapatan masyarakat meningkat dan berdampak pada pendapatan nasional. Dengan meningkatnya pendapatan nasional 
secara otomatis penghimpunan dana pihak ketiga pada bank akan meningkat.

\section{DAFTAR PUSTAKA}

Boediono, 1997. Ekonomi Moneter, BPFE, Yogyakarta.

Fatmawati, Dwi. 2007. Analisis Faktorfaktor yang Mempengaruhi Penghimpunan Dana Masyarakat pada Bank Umum di Wilayah Jawa Timur (1999-2006); Universitas Muhammadiyah Malang.

Gujarati, Damodar. 1999. Ekonometrika Dasar, Erlangga, Jakarta.

Iswardono. 1999. Uang dan Bank; Edisi keempat, BPFE, Yogyakarta.

Judisseno, Rimsky K. 2002. Sistem Moneter dan Perbankan di Indonesia, PT. Gramedia Pustaka Utama, Jakarta.

Kasmir. 2005. Bank dan Lembaga Keuangan Lainnya; Edisi Keenam, PT. RajaGrafindo Persada, Jakarta.

Mankiw, N. Gregary. 2003. Teori Makroekonomi; edisi kelima, Erlangga, Jakarta.

McEachern, William A. 2000. Ekonomi Makro Pendekatan Kontemporer, Penerbit Salemba Empat.

Nopirin. 1992. Ekonomi Moneter. Yogyakarta: BPFE.

Sukirno, Sadono. 2002. Pengantar Teori Makroekonomi, edisi kedua. PT. Raja Grafindo Persada, Jakarta.
2005. Makroekonomi

Modern Perkembangan Pemikiran dari Klasik Hingga Keynesian Baru, PT. Raja Grafindo Persada, Jakarta.

Widowati. 2006. Penentuan Tingkat Suku Bunga dan Tingkat Produk Domestik Regional Brito (PDRB) dalam Penghimpunan Dana Simpanan Berjangka Pada BankBank Swasta di Jawa Timur (19982005);

Universitas Muhammadiyah Malang.

Widarjono, Agus. 2005. Ekonometrika Teori dan Aplikasi untuk Ekonomi dan Bisnis. Ekonsa, Yogyakarta. 